\title{
Evaluation of Transverse Acetabular Ligament Assessment due to Acetabular Labral Tear in Patients Undergoing Magnetic Resonance Arthrography
}

\author{
Manyetik Rezonans Artrografisi Yapılan Hastalarda Asetabular Labral \\ Yırtığa Bağlı Transvers Asetabular Ligamanın Değerlendirilmesi
}

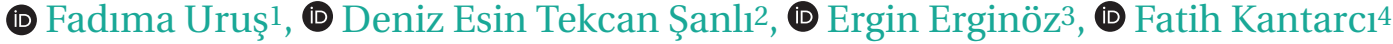

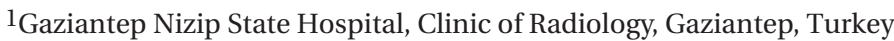

2İstanbul Rumeli University Vocational School of Health Services, Department of Medical Imaging Techniques, İstanbul, Turkey

3̇̇stanbul University-Cerrahpaşa, Cerrahpaşa Faculty of Medicine, Deparment of General Surgery, İstanbul, Turkey

${ }^{4}$ Yedikule Surp Pırgiç Armenian Hospital, Clinic of Radiology, İstanbul, Turkey
\end{abstract}

\section{Abstract}

Objective: In this study, we investigated the relationship between labral tear with its stage and transverse acetabular ligament (TAL) morphology in patients who underwent magnetic resonance arthrography (MRA) examination for acetabular labral tear.

Method: Radiological images of 55 patients who applied to our hospital with MRA for acetabular labral pathology were evaluated. Labral lesions were classified as post-traumatic $(1 A, 2 A$ and $3 A)$ and dysplastic $(1 B, 2 B$ and $3 \mathrm{~B}$ ) according to the Czerny staging system. The widest contact surface and TAL area with the TAL femoral head were measured in MRAs of patients. In the statistical analysis, the widest contact surface of TAL with the femoral head and TAL area were compared to the right and left sides and according to the Czerny classification.

Results: When labral pathologies were evaluated according to the Czerny classification, the widest contact surface of TAL with the femoral head and TAL area, left and right sides, and double groups (1-2,1-3,2-3) in Czerny 1-2-3 classification were compared as post-traumatic (1A, $2 A$ and $3 \mathrm{~A})$ and dysplastic $(1 \mathrm{~B}, 2 \mathrm{~B}$ and $3 \mathrm{~B})$ lesions of the labrum. As a result, no statistically significant difference was observed ( $p>0.05)$.

Conclusion: There was no significant relationship between the staging of acetabular labral pathologies and TAL morphology, suggesting that TAL cannot be shown as a predisposing factor in terms of acetabular labral tear.

Keywords: Acetabular labrum, Czerny classification, labral tear, magnetic resonance arthrography, transverse acetabular ligament

\section{Öz}

Amaç: Bu çalışmada amacımız, asetabuler labral yırtık nedeniyle manyetik rezonans artrografi (MRA) tetkiki yapılan hastalarda labral yırtığın evresi ile transvers asetabular bağ (TAL) morfolojisi arasındaki ilişkiyi araştırmaktı.

Yöntem: Asetabular labral patoloji nedeniyle MRA ile hastanemize başvuran 55 hastanın radyolojik görüntüleri değerlendirildi. Labral lezyonlar Czerny evreleme sistemine göre travma sonrası (1A, 2A ve 3A) ve displastik (1B, 2B ve 3B) olarak sınıflandıııldı. Hastaların MRA'sında TAL femur başı ile en geniş temas yüzeyi ve TAL alanı ölçüldü. İstatistiksel analizde TAL'nin femur başı ile en geniş temas yüzeyi ve TAL alanı sağ ve sol taraflarla ve Czerny sınıflamasına göre karşılaştıııldı.

Bulgular: Czerny sınıflamasına göre labral patolojiler değerlendirildiğinde, Czerny'de TAL'nin femur başı ile en geniş temas yüzeyi ve TAL alanı, sol ve sağ taraflar ve ikili gruplar (1-2,1-3,2-3) 1-2-3 sınıflandırması labrumun travma sonrası $(1 \mathrm{~A}, 2 \mathrm{~A}$ ve $3 \mathrm{~A})$ ve displastik (1B, $2 \mathrm{~B}$ ve $3 \mathrm{~B})$ lezyonları olarak karşılaştııldı. Sonuç olarak, istatistiksel olarak anlamlı bir fark gözlenmedi $(p>0,05)$

Sonuç: Asetabular labral patolojilerin evrelemesi ile TAL morfolojisi arasında anlamlı bir ilişki bulunmamıştır, bu da TAL'nin asetabular yırtık açısından predispozan bir faktör olarak gösterilemeyeceğini düşündürmektedir.

Anahtar kelimeler: Asetabular labrum, Czerny sınıflandırması, labral yırtık, manyetik rezonans artrografi, transvers asetabular ligaman

Address for Correspondence: Deniz Esin Tekcan Şanlı, İstanbul Rumeli University Vocational School of Health Services, Department of Medical Imaging Techniques, İstanbul, Turkey

E-mail: tekcandenizesin@gmail.com ORCID: orcid.org/0000-0002-6545-5757 Received: 12.08.2021 Accepted: 13.11.2021

Cite this article as: Uruş F, Tekcan Şanlı DE, Erginöz E, Kantarcı F. Evaluation of Transverse Acetabular Ligament Assessment due to Acetabular Labral Tear in Patients Undergoing Magnetic Resonance Arthrography. Bagcilar Med Bull 2021;6(4):419-425

${ }^{\odot}$ Copyright 2021 by the Health Sciences University Turkey, Bagcilar Training and Research Hospital Bagcilar Medical Bulletin published by Galenos Publishing House. 


\section{Introduction}

The acetabular labrum seals the joint cavity by deepening the acetabular fossa in the hip joint, providing coxofemoral joint stability, lubrication and articular support (1). In labral tears, this support diminishes and chronic hip, as well as groin pain, occurs. Labral tears result in a significant decrease in the productivity of work and social life in the young and middle age groups. At this point, the prevention of labral tears and preemptive application of preventive medicine come to use. Trauma, degenerative processes, congenital dysplasia, femoroacetabular impingement (FAI), ligamentous laxity, and hypermobility are the etiological factors considered in labral tears. In the study of Ranavat and Kelly (2) that included 300 cases, FAI prevails in etiology with a rate of $55 \%$, while degenerative processes $(48.6 \%)$ stand out in the study of Lage et al. (3). The most common accompanying disease was developmental hip dysplasia in studies performed in Turkey (4). These results indicate that the etiology of labrum pathologies are variable, and studies with larger patient cohorts are needed. Identification of clear and definitive results can eliminate the preventable causes before rupture occurs. This is possible only if the anatomy of the acetabular labrum and adjacent structures are fully understood, where MR arthrography is an excellent imaging modality that shows the labral anatomy clearly. Czerny et al. (5) classified the labral pathologies on MRA according to the Lage's arthroscopic classification. The evaluations made according to the Czerny classification with MRA are largely in agreement with the arthroscopy results. While the sensitivity and specificity of conventional MRI in detecting labral pathologies are $30 \%$ and $36 \%$, these values increase to $90-91 \%$, respectively, with MRA (5).

The acetabular labrum is a fibrocartilage structure composed of collagen fibers that adhere circumferentially to the edge. In the superior part of the acetabulum, the load becomes thinner towards the bearing surface and acetabular labrum increases its depth (6). The acetabulum socket is defective in the inferomedial region in the form of a notch. TAL attaches to the edges of this notch and turns it into a hole. The vessels and nerves, travelling to the joint, pass through this anatomical structure. Acetabular labrum and TAL form $22 \%$ of the hip joint surface and increase the acetabulum volume by $33 \%$. They increase the stability of the hip joint by creating a negative pressure against the displacement of the hip. It was shown that TAL submitted to tension due to natural incongruity (7).

Acetabular labrum tears are one of the most common causes of hip pain presenting with mechanical symptoms. Labral tears can occur from the anterior, posterior and superior due to different factors such as trauma, ligamentous laxity, hypermobility, femoracetabular impingement, developmental hip dysplasia, and degenerative osteoarthritis. Although tears often occur anteriorly, posterior labral tears are more common in young people with hip dislocation or hip dysplasia (8).

To the best of our knowledge, there is no prior study investigating the changes seen in TAL related to ALT. In this study, we evaluated whether there is a relationship between acetabular labral pathologies and TAL morphology on MRA.

\section{Materials and Methods}

\section{Study population}

Patients who underwent MRA examination with a prediagnosis of acetabular pathology at the musculoskeletal imaging center of our hospital between the dates of January 2011 and January 2015 were included in the study. Patients with a history of previous labral surgery, with a tear in the posterior part of the labrum, and with congenital or genetic diseases disrupting normal anatomy in the musculoskeletal system were excluded from the study. The study protocol was approved by İstanbul University CerrahpaşaCerrahpaşa Faculty of Medicine Ethics Committee (date: 09.07.2015, no: 02-218671).

\section{MRA technique}

3D MRA images were taken in the supine position after $20 \mathrm{~mL}$ of gadolinium compound (diluted 1/200) was administered to the coxofemoral joint space under ultrasonography with a $20 \mathrm{G}$ spinal needle. All MRA examinations were performed with a 1.5 T MR device (Magnetom Avanto Siemens Medical Solution). The gradient power of the device was $45 \mathrm{~m} / \mathrm{m}$, and an 8-channeled intraabdominal specific flex coil was used. The MRA protocol was fat-suppressed T1-weighted (T1W) turbo spin echo (TSE), coronal fat-suppressed proton density (FSPD) TSE and transverse T1 VIBE 3D sequences in sagittal, coronal and axial planes. Detailed parameters of the sequences are reported in the supplementary tool (Spll tool).

\section{MRA imaging analysis and measurements}

Imaging assessment was performed in three stages in MRA. First, labrum pathologies were evaluated on transverse T1A VIBE and TSE sequences according to the Czerny classification (Czerny 1A, 1B, 2A, 2B, 3A, 3B) (Figure 1) (5). Taking into account the degree of anteversion of the femoral neck in coronal FSPD TSE images, the widest 
contact surface of the transverse ligament with the femoral head was measured in parallel sections (Figure 2). In the transverse TIW VIBE sequence, the TAL area was measured in the transverse section taken parallel to the collodiaphyseal angle in the coronal section in 3D images (Figure 3). All images were evaluated retrospectively at the PACS-archive system and measurements were calculated digitally using special software programs in Siemens, Syngo via Workstation.

\section{Statistical Analysis}

Statistical analysis was performed using the Statistical Package for Social Science (SPSS, version 20.0) package program. The significance ( $\mathrm{p}$-value) was determined with the Mann-Whitney $U$ test used for non-parametric variables. A p-value less than 0.05 was considered as statistically significant.

\section{Results}

The study included a total of 55 patients. $35 \%$ of patients were male $(n=19)$, and $65 \%$ were female $(n=36)$, with an average age of 40 (15-67) years. Right acetabular labral pathology was found in 54.5\% ( $\mathrm{n}=30)$ of patients and left acetabular labral pathology was detected in $45.5 \%$ $(n=25)$ of the patients. In patients with acetabular labral

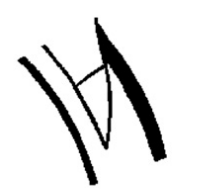

Normal labrum

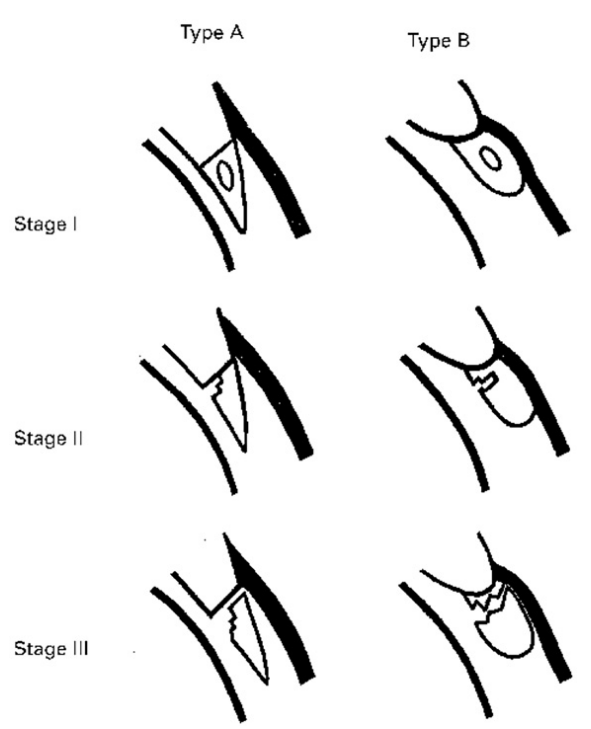

Figure 1. Schematic representation of acetabular labral tears according to the Czerny classification pathology, the widest contact surface of the femoral head and TAL and the TAL area were measured. The results were then compared between left and right sides, among 1-2-3 groups according to the Czerny classification (1-2, 1-3 and $2-3)$, and as post-traumatic (1A, 2A, and $3 \mathrm{~A})$ and dysplastic (1B, 2B and 3B) lesions. There was no statistically significant difference between these parameters $(p>0.05)$. Statistical data of the study are shown in Table 1-3.

\section{Discussion}

ALT causes the joint cartilage to remain unprotected by causing the labrum to separate from the cartilage. As a result, cartilage lesions occur with repetitive collisions of the femoral head and acetabulum, leading to the onset of degenerative joint disease (9). For this reason, the diagnosis and treatment of labral pathologies gain importance in the prevention of both disability and secondary early-onset degenerative processes, especially in young and middleaged patients. In the study conducted by Burnett et al. (10), despite the high sensitivity and specificity of MRA, the average time between the onset of patients' complaints and the diagnosis was found to be 21 months (5). Farjo et al. (11)

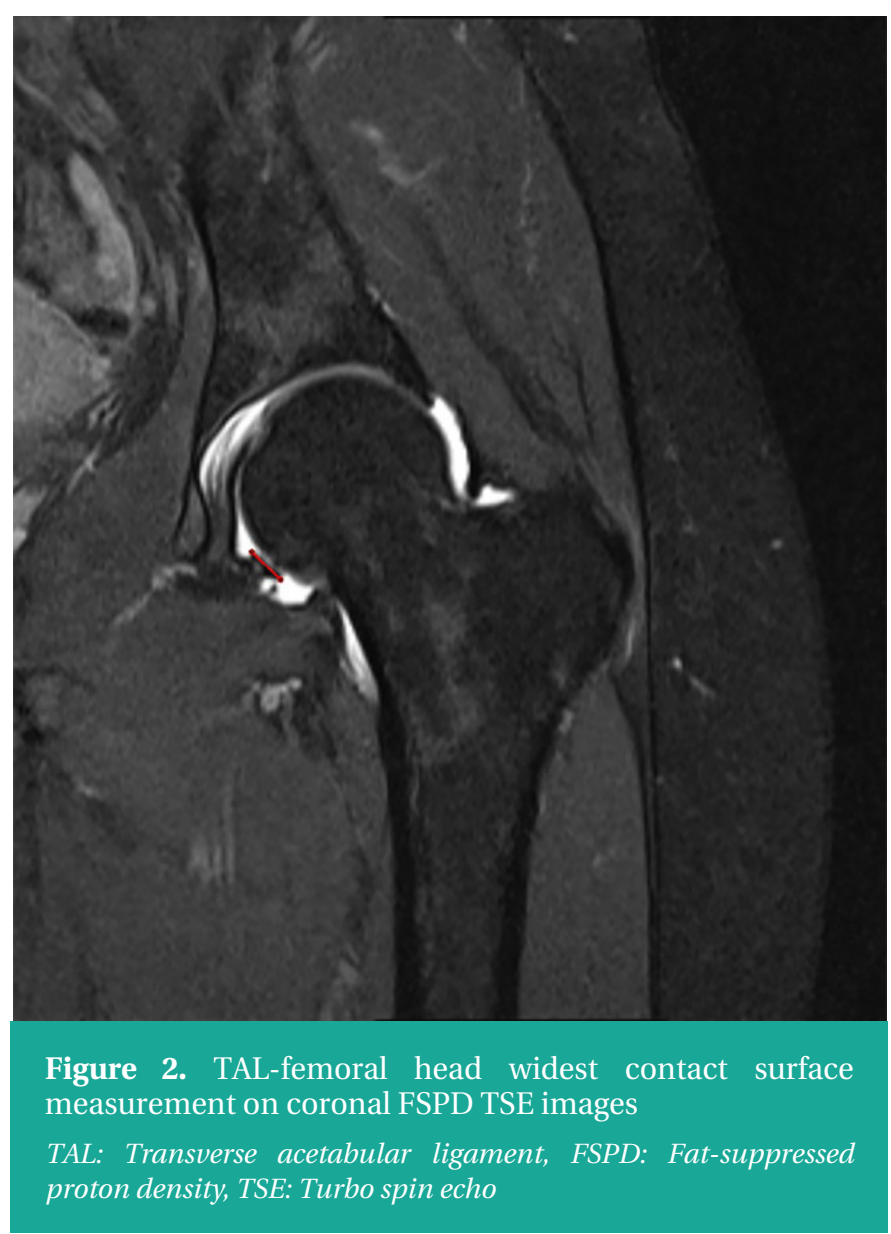



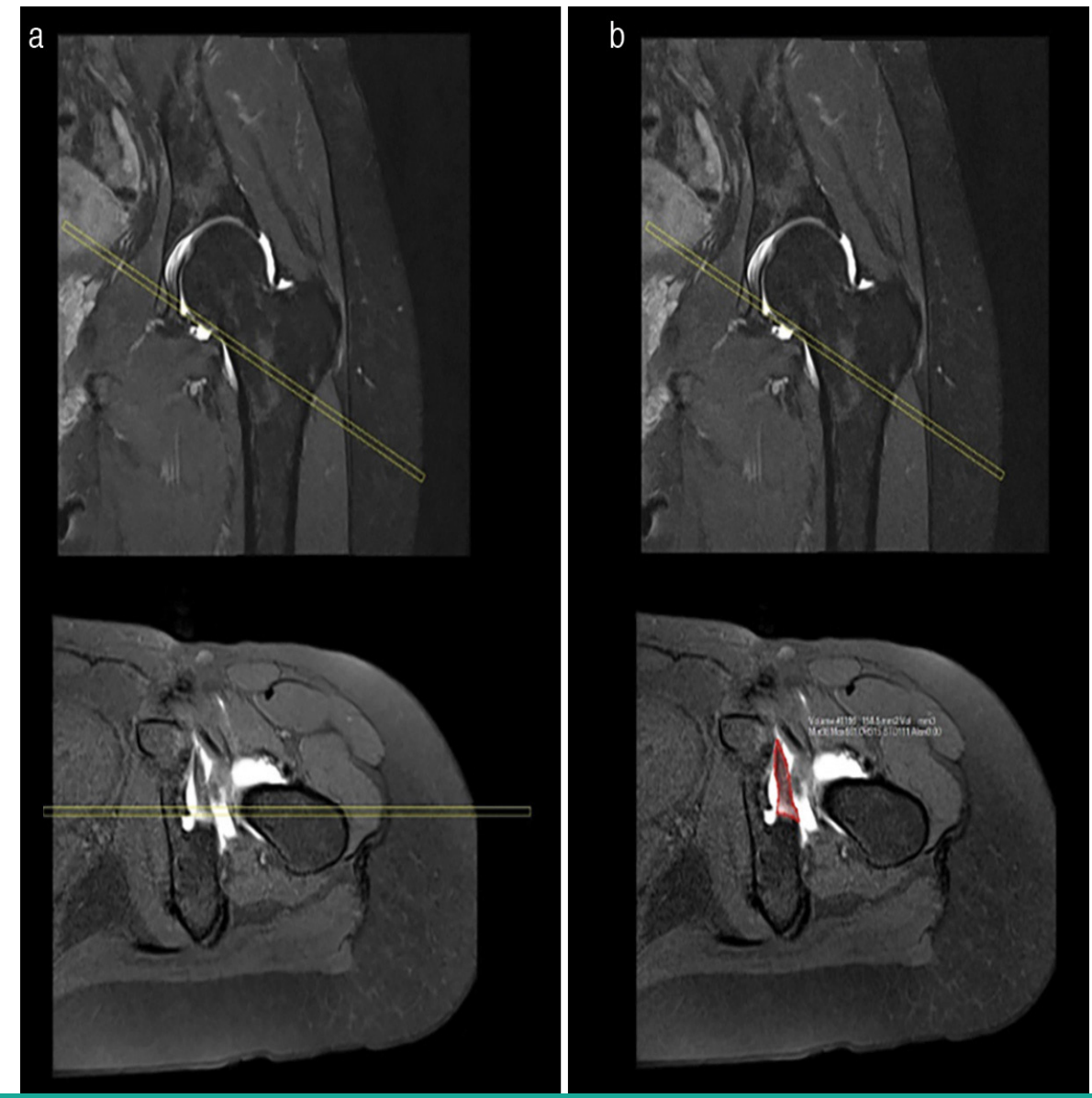

Figure 3. a) The appearance of TAL in the transverse section taken parallel to the collodiaphyseal angle determined in the coronal section in the 3D images in the transverse T1W VIBE sequence, the area measurement is shown in Figure $3 \mathrm{~b}$

TAL: Transverse acetabular ligament, T1W: T1-weighted

obtained similar results for this period. The length of this period may be due to the late presentation of patients to the healthcare institution, as well as insufficient physical examination, incomplete use of diagnostic radiology, misdiagnosis and ineffective treatment. It is essential to reach a diagnosis with increased awareness among the physicians, taking detailed patient history, and completing a thorough physical examination.

TAL is a short fibrous band that acts as a bridge between the two ends of the acetabular notch and is the continuation of the acetabular labrum posteroinferiorly. Biomechanical studies have revealed that during load transport, the acetabular lunate joint face limits the degree to which lunate horns move apart. Thus, the increase in the compressive force applied to the femoral head is prevented by stretching TAL $(12,13)$. The role of acetabular labrum and TAL in hip joint load transfer has been the subject of study for many researchers. However, there is no consensus among researchers on this issue.
Löhe et al. (7) and Vandenbussche et al. (14) have emphasized that TAL plays an important role against the compression of the hip joint, which occurs during the load bearing and which moves the lunate horns away from each other due to native disharmony in the joint. In the immunohistological study conducted by Milz et al. (12) on 8 cadavers, they showed that TAL allowed the fibrocartilage cell layer to withstand the compression that occurred during load transport, both on the inner surface of the femoral head and at both bone junction points (11). However, the fact that these studies were conducted with fixed specimens taken from cadavers makes it impossible to consider the effect of the dense muscle layer surrounding the hip joint on load transfer. Konrath et al. (15) removed the TAL in eight of the hip specimens taken from 17 cadavers and the acetabular labrum in nine of the specimens. They then measured the changes in the contact surface area and pressure distribution between the acetabulum and the femoral head in the samples from which both labrum 
Table 1. Gender distribution according to Czerny classification, transverse ligament-femoral head largest contact surface, transverse ligament area (mean $\pm \mathrm{SD})$ and $(\mathrm{min}$-max) values

\begin{tabular}{|c|c|c|c|c|c|c|c|c|c|}
\hline & $\begin{array}{l}\text { In all } \\
\text { patients } \\
\text { Mean } \pm \text { SD } \\
(\text { min-max })\end{array}$ & $\begin{array}{l}\text { Pathology } \\
\text { in the right } \\
\text { acetabular } \\
\text { labrum }\end{array}$ & $\begin{array}{l}\text { Pathology } \\
\text { in the left } \\
\text { acetabular } \\
\text { labrum }\end{array}$ & $\begin{array}{l}\text { Czerny 1A } \\
\text { Mean } \pm \text { SD } \\
(\text { min-max) }\end{array}$ & $\begin{array}{l}\text { Czerny 1B } \\
\text { Mean } \pm \text { SD } \\
(\text { min-max })\end{array}$ & $\begin{array}{l}\text { Czerny 2A } \\
\text { Mean } \pm \text { SD } \\
(\text { min-max) }\end{array}$ & $\begin{array}{l}\text { Czerny 2B } \\
\text { Mean } \pm \text { SD } \\
(\min -\max )\end{array}$ & $\begin{array}{l}\text { Czerny } 3 A \\
\text { Mean } \pm \text { SD } \\
\text { (min-max) }\end{array}$ & $\begin{array}{l}\text { Czerny 3B } \\
\text { Mean } \pm S D \\
(\text { min-max })\end{array}$ \\
\hline Male & 19 & 14 & 12 & 2 & 1 & 9 & 5 & - & 2 \\
\hline $\begin{array}{l}\text { Transverse } \\
\text { ligament- } \\
\text { femoral } \\
\text { head } \\
\text { largest } \\
\text { contact } \\
\text { surface }\end{array}$ & $\begin{array}{l}8.04 \pm 1.78 \\
(4.3-12)\end{array}$ & $\begin{array}{l}7.79 \pm 1.67 \\
(5.1-11.8)\end{array}$ & $\begin{array}{l}8.33 \pm 1.89 \\
(4.3-12)\end{array}$ & $\begin{array}{l}7.4 \pm 2.28 \\
(4.3-11.3)\end{array}$ & $\begin{array}{l}6.1 \\
(6.1-6.1)\end{array}$ & $\begin{array}{l}8.3 \pm 2.11 \\
(5.3-12)\end{array}$ & $\begin{array}{l}8.08 \pm 1.44 \\
(5.4-10.4)\end{array}$ & $\begin{array}{l}8.4 \\
(8.4-8.4)\end{array}$ & $\begin{array}{l}8.16 \pm 1.08 \\
(6.8-10)\end{array}$ \\
\hline $\begin{array}{l}\text { Transverse } \\
\text { ligament } \\
\text { area }\end{array}$ & $\begin{array}{l}2.06 \pm 0.55 \\
(1.16-3.37)\end{array}$ & $\begin{array}{l}1.97 \pm 0.49 \\
(1.16-3.37)\end{array}$ & $\begin{array}{l}2.18 \pm 0.60 \\
(1.16-3.25)\end{array}$ & $\begin{array}{l}1.98 \pm 0.69 \\
(1.16-3.23)\end{array}$ & $\begin{array}{l}1.64 \\
(1.64-1.64)\end{array}$ & $\begin{array}{l}2.05 \pm 0.46 \\
(1.18-3.14)\end{array}$ & $\begin{array}{l}2.22 \pm 0.66 \\
(1.16-3.37)\end{array}$ & $\begin{array}{l}1.18 \\
(1.18-1.18)\end{array}$ & $\begin{array}{l}1.91 \pm 0.25 \\
(1.6-2.3)\end{array}$ \\
\hline
\end{tabular}

SD: Standard deviation

Table 2. (Mean \pm SD) and (min-max) values of patients with ALT of Czerny type A (1-2-3) and Czerny type B (1-2-3)

\begin{tabular}{llll} 
& $\begin{array}{l}\text { Czerny A } \\
\text { Mean } \pm \text { SD } \\
(\text { min-max) }\end{array}$ & $\begin{array}{l}\text { Czerny B } \\
\text { Mean } \pm \text { SD } \\
(\min -\text { max) }\end{array}$ & p \\
\hline Transverse ligament-femoral head largest contact & $8.05 \pm 2.12$ & $8.03 \pm 1.34$ & $(5.4-10.4)$ \\
surface & $(4.3-12)$ & $2.12 \pm 0.58$ & 0.80 \\
Transverse ligament area & $2.02 \pm 0.53$ & $(1.16-3.37)$ & 0.65 \\
\hline
\end{tabular}

SD: Standard deviation, ALT: Acetabular labral tear

Table 3. Representation of the statistical relationship between the mean \pm SD and min-max values of the patients with ALT according to the Czerny (1-2-3) classification and in pairs in groups

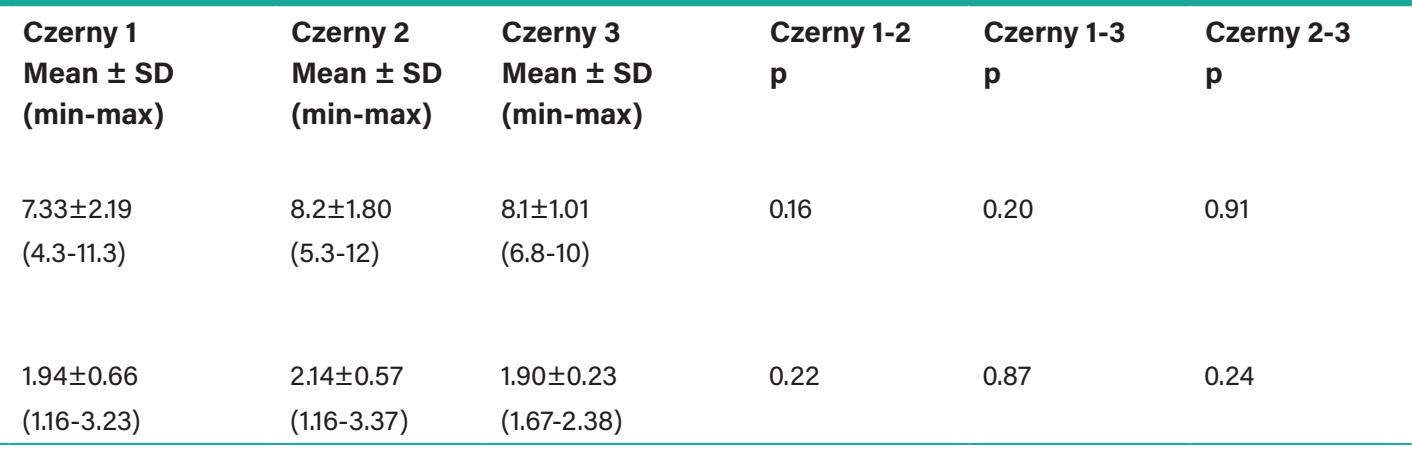

Transverse ligament-femoral head largest contact surface

SD: Standard deviation, ALT: Acetabular labral tear, Mann-Whitney U; $p<0.05$

and TAL were removed (15). As a result, acetabulum and femoral head contact surface area decreased only in the group in which TAL was removed, while no significant difference was found in samples where the labrum or both were removed. There was no difference in the pressure distribution between acetabulum and femoral head in all three groups. These findings led Konrath et al. (15) to state that acetabular labrectomy or TAL removal was not one of the causes of premature osteoarthrosis.
In the study of Löhe et al. (7), it was emphasized that TAL was effective in eliminating the instability caused by the native incompatibility between the acetabulum and the femoral head in the hip joint. It was suggested that TAL played an effective role in carrying the tensile stress that occurred especially during physical activities such as walking (13). Various anatomical and physiological studies have noted a clear stress on TAL; however, no study is available demonstrating the changes of TAL in patients 
with acetabular labral tear. Our study showed that there was no gross morphological change at TAL on MRA in patients with acetabular labral tear.

Another area where TAL gains importance is its use for orientation in total hip replacement operations. According to Kalteis et al. (16), when TAL and posterior labrum were used for soft tissue orientation in the placement of the acetabular component, it was shown that it provided less malposition rate compared to traditional methods. In a study published recently by Harris et al. (17), the role of TAL in terms of treatment and recovery in acetabular pathologies has also been emphasized by showing that the healing rates of labral tears that cannot be repaired with the labral reconstruction method including the transverse acetabular ligament are favorable.

Until now, there has been no study in the literature evaluating the widest contact surface of TAL with the femoral head and TAL area in patients with acetabular labral pathology. In this study, we compared the mean values of these two parameters with respect to the right and left sides. However, we could not find any significant difference in these values. In the parameters measured in ALTs which were evaluated according to the Czerny classification, no significant difference was found between the Czerny 1-2-3 groups in the comparisons made in pairs. In addition, the widest contact surface and area of TAL with the femoral head were measured between posttraumatic (1A, 2A and 3A) and dysplastic (1B, 2B and 3B) lesions of the labrum, and no significant difference was found.

\section{Study Limitations}

Our study has a number of limitations. The most important limitation is that the arthroscopic response of labrum pathologies described with MRA is not investigated. Arthroscopy is still the gold standard in the diagnosis of acetabular labral pathologies. According to Chan et al. (18), the sensitivity of MRA is $100 \%$, while the accuracy rate is $94 \%$. This rate is due to false-positive results. Another limitation is the exclusion of posterior labral pathologies from the study. TAL is the continuation of the posterior labrum and there are significant changes in TAL morphology in its pathologies; it is necessary to evaluate the anterior-superior and posterior lesions in separate groups. This area may serve as a starting point for further studies in the future. In addition, in a small number of patients evaluated in the study, the TAL orientation was not taken into account. Lack of knowledge on presenting complaints and clinical findings of acetabular labrum pathologies is among other limitations.

\section{Conclusion}

We found no significant relationship between Czerny staging of acetabular labral pathologies and transverse acetabular ligament morphology. This result suggests that transverse acetabular ligament morphology cannot be indicated among the predisposing factors in acetabular labral pathologies. Considering that TAL, which has an important role in acetabulum and labrum mechanics, may theoretically be associated with these pathologies, more detailed studies will be required in the future to prove this relationship.

\section{Ethics}

Ethics Committee Approval: The study protocol was approved by İstanbul University Cerrahpaşa-Cerrahpaşa Faculty of Medicine Ethics Committee (date: 09.07.2015, no: $02-218671)$.

Informed Consent: Written informed consent was not necessary because no patient data has been included in the manuscript.

Peer-review: Externally peer-reviewed.

\section{Authorship Contributions}

Concept: F.U., D.E.T.Ş., F.K., Design: F.U., D.E.T.Ş., F.K., Data Collection or Processing: F.U., D.E.T.Ş., E.E., Analysis or Interpretation: D.E.T.Ş., F.K., Drafting Manuscript: F.U., D.E.T.Ş., E.E., Critical Revision of Manuscript: F.K., D.E.T.Ş., E.E., Final Approval and Accountability: F.K., F.U., D.E.T.Ş., E.E.

Conflict of Interest: No conflict of interest was declared by the authors.

Financial Disclosure: The authors declared that this study received no financial support.

\section{References}

1. Aprato A, Masse A, Faletti C. Magnetic resonance arthrography for femoroacetabular impingement surgery: is it realible? J Orthop Traumatol 2013;14(3):201-206.

2. Ranavat AS, Kelly BT. Function of the labrum and manegement of labral pathology. Oper Tech Orthop 2005;15(3):239-246.

3. Lage LA, Patel JV, Villar RN. The acetabular labral tear: an arthroscopic classification. Arthroscopy 1996;12(3):269-272.

4. Sozen YV, Ozkan K, Goksan SB, Ciftçi F, Mutlu S, Uzer G. Arthroscopic diagnosis and treatment of an acetabular labrum bucket handle tear: a case report. Arch Orthop Trauma Surg 2005;125(9):649-652. 
5. Czerny C, Hofmann S, Neuhold A, Tschauner C, Engel A, Recht $\mathrm{MP}$, et al. Lesions of the acetabular labrum: accuracy of MR imaging and MR arthrography in detection and staging. Radiology 1996;200(1):225-230.

6. Huffman GR, Safran MR. Arthroscopic treatment of labral tears. Oper Tech Sports Med 2002;10(4):205-214.

7. Löhe F, Eckstein F, Sauer T, Putz R. Structure, strain and function of the transverse acetabular ligament. Acta Anat (Basel) 1996;157(4):315-323.

8. Blankenbaker DG, De Smet AA, Keene JS, Fine JP. Classification and localization of acetabular labral tears. Skeletal Radiol 2007;36(5):391-397.

9. Steinbach LS, Palmer WE, Schweitzer ME. Special focus session. MR arthrography. Radiographics 2002;22(5):1223-1246.

10. Burnett RS, Della Rocca GJ, Prather H, Curry M, Maloney WJ, Clohisy JC. Clinical presentation of patients with tears of the acetabular labrum. J Bone Joint Surg Am 2006;88(7):1448-1457.

11. Farjo LA, Glick JM, Sampson TG. Hip arthroscopy for acetabular labral tears. Arthroscopy 1999;15(2):132-137.

12. Milz S, Valassis G, Büttner A, Maier M, Putz R, Ralphs JR, et al. Fibrocartilage in the transverse ligament of the human acetabulum. J Anat 2001;198(Pt 2):223-228.

13. Benjamin M, Ralphs JR. Functional and developmental anatomy of tendons and ligaments. In: Repetitive Motion Disorders of the
Upper Extremity. Illinois: American Academy of Orthopaedic Surgeons, 1995:185-203.

14. Vandenbussche E, Massin P, Augereau B, Lavaste F. Etude cadavérique de la mobilité des cornes acétabulaires de la hanche saine et prothésée par simulation d'appui monopode [Cadaver study of acetabular cup mobility in the healthy hip and prosthesis by monopodal pressure simulation ]. Rev Chir Orthop Reparatrice Appar Mot 1999;85:136-145. (French)

15. Konrath GA, Hamel AJ, Olson SA, Bay B, Sharkey NA. The role of the acetabular labrum and the transverse acetabular ligament in load transmission in the hip. J Bone Joint Surg Am 1998;80(12):17811788.

16. Kalteis T, Sendtner E, Beverland D, Archbold PA, Hube R, Schuster $\mathrm{T}$, et al. The role of the transverse acetabular ligament for acetabular component orientation in total hip replacement: an analysis of acetabular component position and range of movement using navigation software. J Bone Joint Surg Br 2011;93(8):1021-1026.

17. Harris JD, Brand JC, Rossi MJ, Lubowitz JH. Irreparable hip labral tears and femoroacetabular impingement syndrome: labral reconstruction incorporating the transverse acetabular ligament may restore the suction seal. Arthroscopy 2020;36(10):2573-2577.

18. Chan YS, Lien LC, Hsu HL, Wan YL, Lee MS, Hsu KY, et al. Evaluating hip labral tears using magnetic resonance arthrography: a prospective study comparing hip arthroscopy and magnetic resonance arthrography diagnosis. Arthroscopy 2005;21(10):1250. 